\title{
A new perspective of e-trust in the era of social media: Insights from customer satisfaction data
}

\author{
Usha Ramanathan, Nigel L.Williams, Michael Zhang, Punyachalee Sa-nguanjin, \\ Jose Arturo Garza-Reyes and Lilian Adriana Borges
}

\section{Managerial relevance:}

In this competitive business world, social media penetrates online sales very rapidly. Businesses operating online are required to provide a safe and secured environment for customers to ensure their satisfaction. Our research results confirm that in addition to social media advertising, guaranteed 'esafety' for customers will help establishing trust between the customer and the online businesses; it is also viewed important for present and future sales. The social media reviews need to be incorporated in managerial decision making. We try to analyse how these reviews are changing over the period of time and what are the ways to enhance customer satisfaction using information on customer expectations. This paper can help service companies to position their websites to compete in the market.

\begin{abstract}
In this era of social media, products and services are sold globally using a few simple clicks online. In such online purchases, trust and familiarity are considered two important driving forces of consumer decision making. While online sales advocate high levels of flexibility and choices for consumers, they also hold the online service provider responsible for ensuring the security of the online user's data. Using a Structural Equation Model (SEM) with data collected from the online service industry, we test the direct effects of 'social media-induced purchase intention' on customer satisfaction. We also test the mediating role of e-commerce/online sales (eadvertisement, e-safety and e-information) on customer satisfaction. In addition to social media advertising and information sharing, we find that a new factor - 'e-safety' - mediates the relationship between customer purchase intention and customer satisfaction. Our analysis indicates that online e-trust can be established between the customer and the service company when online purchases are made. At the same time, the quality of online information and e-safety of online payments make the service company trustworthy for future purchases. We relate data analysis directly to managerial decision making to avoid any delay in online customer services in the era of social media.
\end{abstract}

Keywords social media, e-safety, customer satisfaction, online trust, SEM

\section{Introduction}

In recent years, service industry around the globe experienced great turbulence due to economic recession, natural calamity and political instability. Some service industries have embraced social media as a means of online advertising as well as a tool for collecting detailed customer feedback to improve performance. In this context, we consider one specific industry -the tourism industry - since it operates globally using online media, such as websites and social media, for advertising and sales (Leung, Law, Van Hoof \& Buhalis, 2013). 
Over the past two decades, the service sector globally has experienced challenges from rapid technological change and economic volatility. Many service operators have not only had to cope with these global forces but have also faced specific regional and local challenges, such as the 2008 global financial crisis and political instability. Despite these challenges, online purchases have steadily increased (Kumar \& Kumar, 2019).

In order to compete, service industries deployed social media advertising to attract customers. Helped by the rapid development of information and digital technologies, many service organisations moved from traditional to online advertising to take advantage of the manageable and interactive tools available (HernáNdez et al., 2010; Ramanathan, 2011). Tourism services around the world now use social media to promote the destination as a whole and also to highlight the network of hotels and services available to potential tourists (Kim, Lee, Shin \& Yang, 2017).

Previous research has identified general factors, such as assurance of the products, delivery of products, payment methods and physical sense of the products play important roles in consumers' intentions to purchase/re-purchase products or services via the internet (Martin \& Herrero, 2012; Hudson \& Thal, 2013). However, it is still difficult to identify which particular aspects of social media encourage purchase behaviour; therefore, it is difficult for service providers to predict actual demand (Martin \& Herrero, 2012).

The literature on consumer trust in e-commerce has attempted to understand online consumer behaviour (Gefen, 2000; Gefen \& Straub, 2004; Kim, Ferrin \& Rao, 2008). However, research on technology interventions, such as the internet and social media, in online sales or customer behaviour have not yet resulted in the creation of new management theory (Maillet et al., 2015; Sila, 2015). Theoretical perspectives from technology, namely Technology Acceptance Model (TAM), Extended TAM and Igbaria's Model and Diffusion Theory, have been utilised to examine trust-based online consumer behaviour (Davis et al., 1989; Maillet et al., 2015; Igbaria, 1994; Lin \& Chan, 2008; Sila, 2015). Further, little of this literature has currently examined customers in developing countries. Customer trust in e-commerce is a critical factor in facilitating online transactions which may be encouraged by the presence of informational content, reviews and security features of websites (Filieri, Alguezaui \& McLeay, 2015). In this article, we name the online content as e-information and the online security features as e-security. These characteristics may be viewed as signals (Wang, Qu \& Tan, 2018) by customers that a given provider can deliver the required offerings (Ray, Ow \& Kim, 2011). If customers perceive these signals as valid, they may trust the provider and engage in purchase. As online trust is hard to measure directly, we try to interpret e-trust as customers' intention to purchase via online sites based on their perceptions of various attributes of sales and services (Razak et al., 2019).

Social media is currently a distributor for both user-generated content and online advertising. For the latter, service organisations use a variety of social media platforms, viz Instagram, Twitter, Facebook, Linkedin; we include all these under the category 'social media'. To understand the influence 
of social media (specific to e-commerce factors) on tourists' intention to purchase travel tickets online and to identify the role of e-information in tourists' choices, we conducted a study on Thailand Tourism Services. In this context, e-information refers to online information related to a service company and its offerings. The main objectives of this study are: (1) to understand the role of e-information, particularly e-safety and e-security, in influencing service satisfaction; (2) to explore the influence of social media on services, such as advertising, information and decision speed, that contribute to tourists' e-trust and (3) to act on service-specific factors identified through data analysis to enhance customer satisfaction and sales.

This paper is organized into 6 sections. Section 2 reviews the relevant literature and the theoretical background to the field of discussion before developing the research hypotheses. Section 3 explains the research methodology in more detail together with data description. Meanwhile, Section 4 analyses the survey responses and reports the findings and Section 5 summarises the key findings and provides interesting managerial implications. This is followed by conclusions and limitations of this study together with suggestions for future research directions.

\section{Research background and hypothesis development}

\subsection{Underlying theoretical background}

\section{Developing trust for customer satisfaction}

Trust has been studied and interpreted by various disciplines, such as economics, sociology and psychology (Blau, 1964; Chua, Morris \& Ingram, 2009; Das \& Teng, 1998; Gefen \& Straub, 2004; Mayer et al., 1995). Despite the differences in theoretical perspectives and methodological approaches, business and management scholars have reached a widely-agreed definition of trust as "a psychological state comprising the intention to accept vulnerability based upon positive expectations of the intentions or behaviour of another” (Rousseau, Sitkin, Burt \& Camerer, 1998, page 395). Vulnerability is a distinctive feature of trust relationships in our daily social exchanges (Blau, 1964). Particularly, on social media platforms, users are vulnerable because their data can be exposed to others and, hence, they expect trustworthy sellers when they buy online. In the Business to Consumer (B2C) platform, where interpersonal interaction is lacking, online businesses can gain customers' trust by increasing their feelings of security in the site by providing an 'e-trust platform' (Gefen \& Straub, 2004). Trusting customers anticipate that the trusted business provider will behave as expected (Gefen \& Straub, 2004; Mayer et al., 1995). In other words, in making purchase decisions, customers will only accept vulnerability with the expectation that the seller will perform a particular action (Das \& Teng, 1998) over which they have no control (Greenwood \& Van Buren III, 2010). In the absence of control and monitoring, which is often the case for online B2C platforms, customers are particularly vulnerable as they put their trust in the seller based on their instincts, which is termed 'affect-based' trust (Chua et al., 2009). In such circumstances, the seller is required to provide customers with reliable services to 
maintain trust (Rousseau et al., 1998). Trust is a well-established social and psychological concept discussed in the literature. Therefore, in the context of social media, we can assert that trust is a basis for online sales and can be deliberated as a major antecedent of online business transactions to consider the seller a 'trustworthy online seller' (Li et al., 2012). In the online platform, not only do e-sellers need to develop such trust but they also need to keep customers satisfied and with future intentions to purchase, by maintaining their trustworthiness (Gefen \& Straub, 2004).

\subsection{Research background}

To achieve our research objectives, we began by searching the extant literature in the service industry specific to the tourism sector. Second, we searched for the role of e-information, particularly e-safety, e-trust and e-security, specific to the service satisfaction of tourism.

\subsubsection{Underlying factors of service customers' online purchase decisions}

From the extant literature searches, 'tourist destination image' emerged as one of the influencing factors of demand for e-tourism services. For potential visitors, the Tourism Destination Image (TDI) provides a means to evaluate possible destinations in terms of attractiveness, safety and value for money. Other factors, such as price, climate and friendly atmosphere, also play critical roles in tourists' decision making on their holiday destinations (purchase tickets). Based on these factors, we developed our research hypotheses below.

In tourism, services and hospitality offerings are complex aggregations of intangible and tangible items that make it difficult to evaluate pre-consumption. These include businesses that directly serve customers, such as transport, accommodation and entertainment services, along with other organisations that support tourists' experiences. While a significant amount of research has been conducted in the area of TDI, the meaning of the term is still debated (García et al., 2012). The prevailing perspective is that TDI refers to the overall impression of one place (Bigne, Sanchez \& Sanchez, 2001) by relevant stakeholders; in other words, TDI is a way of looking at service quality. In the era of the internet, TDI is highly reliant on images (such as photos and pictures) and the quality of online information available to customers.

In examining the complex, multidimensional nature of destination image, Echtner and Ritchie (1993) modelled the concept as occupying a position on three continuums: (1) attribute-holistic, (2) functional-psychological and (3) common-unique. The first continuum is based on how customers evaluate products based on individual attributes versus overall, holistic perceptions (Maclnnis \& Price, 1987). The second continuum suggests that destinations, like products, can be evaluated based on observable (i.e. tangible), functional characteristics or psychological (i.e. intangible) characteristics. Finally, destinations also exist in a competitive context and have common characteristics such as 
exchange rates and promotions that can be compared to those in other locations (Baloglu \& Brinberg, 1997). They also have unique destination-specific characteristics that serve to attract tourists (Holloway, 2006; Ng et al., 2007).

Some researchers have argued that TDI consists of all that the destination evokes in the individual, such as ideas, beliefs, feelings or attitudes, that the tourist associates with a given place (Bigne et al., 2001). The latter definition can be decomposed into cognitive, affective and conative components (Bigne et al., 2001). The cognitive component takes a rational perspective to examine a potential visitor's knowledge and beliefs about the destination (Gallarza, Saura \& García, 2001). In contrast, the affective component examines the feelings or sentiments that potential visitors have towards the destination (Baloglu \& Brinberg, 1997). Finally, the conative (or behavioural) component (Pike \& Ryan, 2004) goes beyond knowledge or sentiment to consider the behavioural aspects of a potential visitor's destination perception.

With the shift to online methods of promotion, information to support the development and evaluation of TDI is provided via the internet. These tools attempt to position the destination in the eyes of customers, leading to the legitimate challenge of the validity of TDI information provided online. Destination stakeholders use language, images, video and sound to build an impression in the minds of customers that are tailored to encourage purchase. At the same time, user-generated media provides an alternate impression of a destination that may not align with the promotional attempts of destination stakeholders (Hunter, 2016). This scenario raises an additional challenge in seeking to understand the influence of social media on visit intention as these multiple sources make it difficult to determine which destination characteristics and media presentations encourage the purchase decision or e-trust. Therefore, there is a need to understand the underlying factors of TDI and their effect on the online purchase decision.

\subsubsection{Cognitive, Affective and Conative factors of tourism customers' purchase decisions}

Tourist destinations and destination image play vital roles in influencing tourists' levels of satisfaction along with other factors, such as access, population concentration, physical facilities and intervening opportunities (Jenkins, 1999). Physical characteristics, attractions and services can make a country appear an attractive tourist destination. These include natural beauty (e.g., mountains, beaches, and good weather) that attract tourists (Ng et al., 2007). Tourists also expect attractions, such as shopping areas and historical experiences and services in transportation, accommodation and information centres, and the infrastructure to support tourism (Holloway, 2006).

Several factors influencing potential visitor choices were identified from the previous research and these include promotional offers, entertainment and food (Hsieh \& Chang, 2006; Rittichainuwat Qu \& Mongkhonvanit, 2006). Factors, such as beaches, resorts, restaurants, historical attractions, cultural diversity and low prices, play a significant role in influencing customers' choices (Bigne et al., 
2001; Pearce \& Butler, 1993; Rittichainuwat et al., 2006). In some locations, it is also important to be informed about the crime rate and the safety and security indices (Hsieh \& Chang, 2006; Pearce \& Butler, 1993). Further, cleanliness, language and communication are all-time winners of customers' choice (Ng et al., 2007). At this point, it is interesting to note that these articles have not discussed trust or ethics in great detail in the context of tourism services.

Tourists may exhibit trust in a given destination based on knowledge or cognitive-based perception of the ability to provide desired services, infrastructure and experiences (Artigas, Yrigoyen, Moraga \& Villalón, 2017). Previous research has indicated that there is a relationship between the degree of online trust that individuals or groups have in an institution and their perception of the institution (Punyatoya, 2019). Presentation of the destination's physical and heritage assets in a credible manner to potential visitors can engender trust in the service provider. For host locations, a positive perception of destination characteristics and services can encourage the development of potential visitor trust in online settings.

Thus, the authors propose the following hypothesis

\section{H1 E-trust is influenced by knowledge of a destination's service characteristics}

Other than safety and hospitality, destinations have common characteristics that should meet travellers' demands (Maclnnis \& Price, 1987). If a destination does not have these characteristics, it may not be considered by potential customers. Ng et al. (2007) classified customers' behaviour according to their travel patterns and other activities. Service expectations of various customer groups from around the globe vary widely. Accordingly, Japanese customers tend to use tour packages for their vacations and prefer a relatively shorter holiday whereas German and other European travellers tend to take longer holidays by booking resorts, including other facilities (e.g., spa facilities).

Furthermore, American travellers often prefer to socialise with other international tourists, which is in contrast with Japanese and Korean tourists who like to be more private. In order to be considered as a destination, the destination itself needs to meet these basic service expectations for a range of holiday visitors (Rittichainuwat et al., 2006). The cognitive perceptions of a service provider, in this case, a destination's ability to meet these expectations of potential visitors, may be a prerequisite to the development of trust (Lankton \& Wilson, 2007). Based on the above observations, we propose our second research hypothesis related to basic service expectations.

\section{H2: E-Trust is influenced by the presentation of potential visitors' basic service expectations}

In addition to service expectations, tourists may have requirements for differentiated experiences or personalised service expectations. Perception of the destination's ability to meet these requirements may create a positive or negative affective evaluation (Kock, Josiassen \& Assaf, 2016). In a similar manner to cognitive evaluations, positive affective evaluations may encourage the development of trust 
in an institution or destination (Marinao, Chasco \& Torres 2012). Based on the above evidence, we propose our third research hypothesis:

\section{H3: E-Trust is influenced by potential visitors' personalised service expectations}

Social interactions with host service providers and residents underpin experiential activities at destinations. The perceptions of these interactions as sincere and not merely functional can play important roles in customers' decision-making processes while selecting holiday destinations (Hsieh \& Chang, 2006). Trust may be created if visitors believe that these sincere social interactions will occur at a given destination (Su, Lianm \& Huang, 2020). Based on the above literature, we propose our fourth research hypothesis related to safe players:

\section{H4: E-Trust is influenced by potential visitors' personal service expectations}

\subsubsection{Customers’ service satisfaction from online booking}

Satisfied customers tend to revisit Thailand (Rittichainuwat et al., 2006) and generate positive word-of-mouth (WOM) (Ng et al., 2007). We test the post-experience of customers of Thailand tourism services with the following hypothesis:

\section{H5: Customers' satisfaction is positively related to their E-Trust}

Social media information (via the internet) has become the primary source of information for making travel decisions. Increasingly, tourists' initial contact with the destination is via online information provided or reviews posted by past visitors. This mediator has characteristics that can influence tourists' perceptions and, hence, destination image.

In light of the rapid development of e-commerce in the era of social media, tourism is commonly evaluated, promoted and purchased by users of the internet (Internet World Stats, 2011) as it facilitates potential buyers making their purchase decisions (Hui \& Wan, 2007). In terms of evaluation, the internet provides online information about the business (e-information) that influences purchasing behaviour (Law, Leung \& Wong, 2004). Early models of vacation buyers adopted a deterministic view of purchase behaviour, modelling the process as a life cycle of problem recognition, information scanning, evaluation of alternatives, purchase decision, purchase and evaluation of outcomes. This approach has been used to analyse vacations purchased by families and individuals (Um \& Cromption, 1990). However, in recent times, due to the complexity of leisure product offerings, individuals have to make decisions beyond destination choice, such as choice of transportation facilities and provision of available technologies to maintain uninterrupted communication, as well as leisure services. The process also has a degree of contingency as previous choices influence subsequent decisions

Decisions before travel may be rational, incorporating predetermined criteria and formalised evaluation processes (Fesenmaier\& Jeng 2000). An extensive information search is conducted and the content, quality and source of data are assessed and used as a basis for decision making (Um \& Crompton, 1990). 
After travel, the output of this assessment will also be evaluated against the criteria established earlier and it forms the basis of future evaluation. In contrast, decisions made during travel may follow a less rational process. Based on the nature of the trip, individuals may adopt an experimental approach, trying an option with minimal information search and no predetermined assessment criteria (Hyde, 2007). After the experiment, the experience will be reviewed and the information used to create assessment criteria for future activities. In a wider context, these tourists' experiences and their behaviour are greatly affected by the presence of the internet.

Potential customers begin their assessment of destinations with a review of online sources (Law et al., 2004) that incorporates a review of destinations, flight schedules, accommodation and other travelling expenses. At the same time, this is a cheap option for service providers wishing to advertise and promote their products. Many tourism organisations around the globe view internet advertising as a cost-effective channel to engage customers (Wu \& Chang, 2005). Unlike other forms of promotion, internet advertising in social media can go beyond providing information to incorporate interactions, such as purchase and returns (Ramanathan, 2011, 2012). These e-adverts and social media advertising serve the purposes of enhancing customers' engagement and helping them retain some degree of control over the travel planning process (Hui \& Wan, 2007). Internet advertising comes in different forms, of which three major forms are the World Wide Web (WWW), social networks, and advertising in own/others' websites using blogs and feedbacks. Some tourist websites collaborate with many service operators to provide rich data for potential travellers (e.g., thomascook.com, travelsphere.co.uk, holidayhypermarket.co.uk, laterooms.com and booking.com). Based on the above literature, we propose our next two research hypotheses.

H6: E-advertising will mediate the relationship between online purchase intention and satisfaction.

\section{H7: E-information will mediate the relationship between online purchase intention and} satisfaction.

\subsubsection{Quality and security concerns of internet advertising and information}

High-quality online sources attract a huge amount of customer attention. For internet advertising, the quality of information, such as pricing, transparency and images, plays an important role in persuading users' perceptions or behaviour. However, since online websites facilitate purchase as well as promotion, potential travellers are wary of payment risks (Wu \& Chang, 2005). Customers have long been sensitive to security concerns, and this sensitivity has heightened with recent high-profile information breaches involving customers of Wonga and TalkTalk, among others. Customers also evaluate the potential for loss of personal or financial information which may be used negatively against them in the future. These risks are somewhat mitigated by travel sites that provide customer service as 
well as security features (Vail, Earp \& Antón, 2008). Overall, this suggests that tourism websites with security features may be perceived as high-quality sources and are more likely to encourage purchase by travellers. This, in turn, can increase a customer's satisfaction in e-purchase.

In the existing literature, many researchers have highlighted the importance of e-commerce and social media (Ramanathan et al., 2012, 2017). However, ever-changing customers' behaviour and buying patterns challenge all businesses and e-commerce is no exception. Specifically, security, privacy risks and product returns are considered as major issues in online sales (Hofacker \& Murphy, 2000; McCole, Ramsey \& Williams, 2010; Park, Han \& Park, 2013; Ramanathan, 2011). The increasing growth of e-commerce has exacerbated these issues. Based on the above arguments, we propose our last research hypothesis.

H8: E-security will mediate the relationship between e-trust and satisfaction.

The above-aforementioned factors and hypotheses are conceptualised in Figure 1.

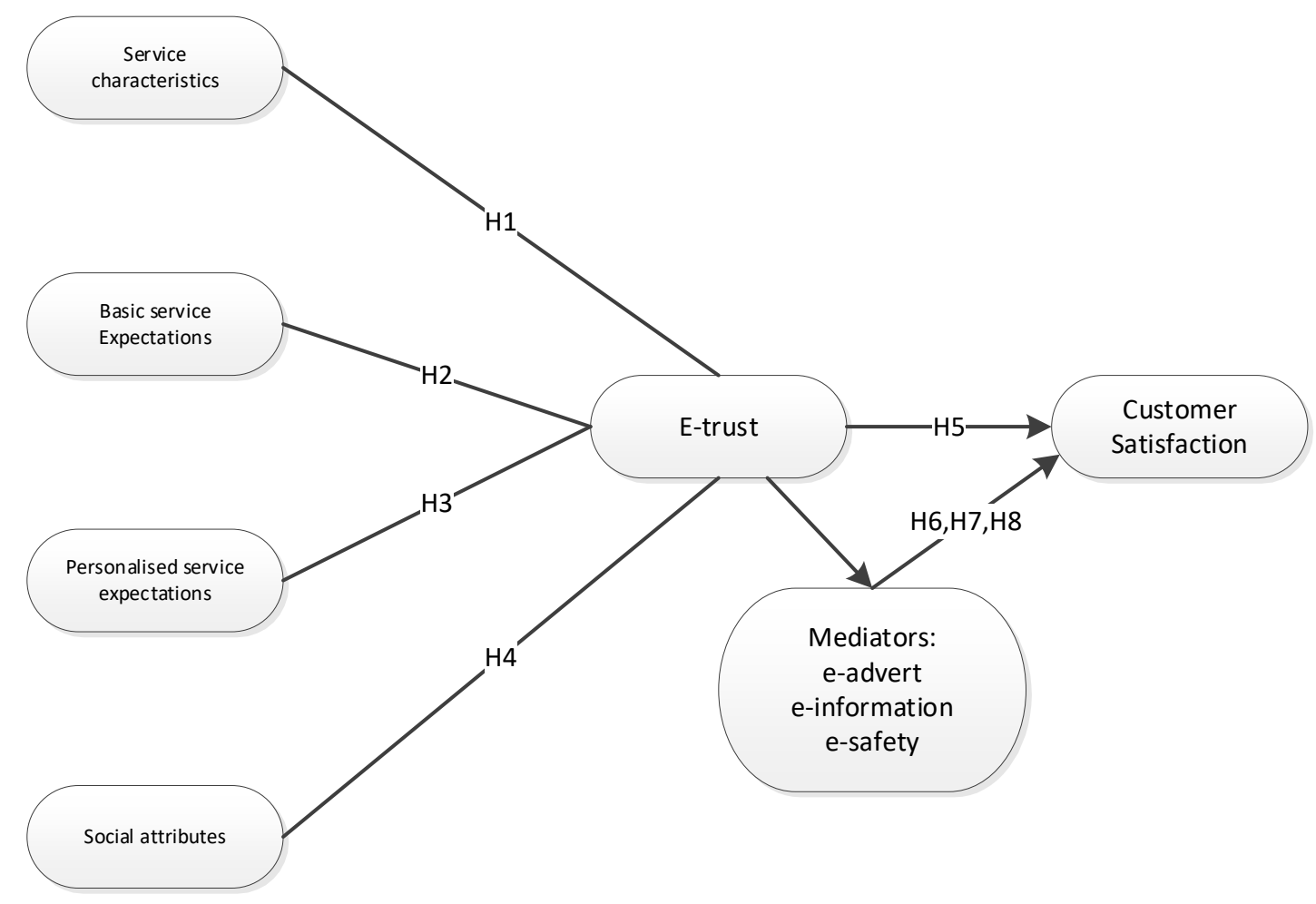

Figure 1: Online sales: Customer satisfaction model.

\section{Research methods and data description}

In order to test the research hypotheses proposed in Section 2, we surveyed international tourists visiting Thailand during the summer period (June and July) and applied structural equation modelling (SEM) to confirm the factors influencing customers' intentions and decisions to visit Thailand 
(Ramanathan \& Muyldermans, 2010). We used a random and convenient sampling approach (Saunders, 2009).

The questionnaire is divided into three sections; each contains various types of question, including multiple-choice ratings with a 5-point Likert scale and a suggestion box to maintain the respondents' interest. In the first section, tourists are asked about their travel habits, as well as other factors that influence their e-trust via intention to purchase services online. The findings from the first section will assist the authors in identifying the relationships between variables and factors. The second section focusses on the influence of internet advertising and how the influencing factors of internet advertising and internet users have indicated the degree of their agreement. This section also uses the same types of question as in the first section (i.e. seeks the relationships between variables and factors). The third section collects demographic information, such as gender, age, region and annual income of tourists. The data collected were used to analyse further the variables that affect customers' decisions (intentions) to visit Thailand. We also analysed the data in order to understand the influence of internet advertising on customers' visits and satisfaction.

We reviewed academic literature and visited published sources (such as magazines and newspapers, as well as the Tourism Authority of Thailand (TAT) website) to develop our survey questionnaire. Initially, we pilot-tested the questionnaire before disseminating the actual survey questionnaires to the sample population. Ten researchers experienced in online purchase behaviour were involved in the pilot stage. This stage tested the content and logic of the questionnaire. The questionnaire was then amended based on their feedback and suggestions. We used the convenience sampling technique by considering factors, such as time consumption and low costs, among others. The sample population consisted of tourists who were influenced by internet advertising when they made their decision to visit Thailand.

The respondents - tourists from around the world - were selected at random and the questionnaires were directly distributed to this sample in person. In total, 300 questionnaires were distributed in highly populated tourist locations. Two hundred and fifteen respondents completed the questionnaires and only 15 were incomplete. To ensure the collected data were highly reliable and valid, the authors distributed the questionnaires to tourists from different continents and regions, which further ensured the data collected fully qualified for this study and for testing the hypotheses.

We used SPSS for the descriptive analysis, such as frequency, reliability and correlation and the factor analysis. Out of the 200 fully usable and completed responses, 98 and 102 were female and male tourists, respectively.

In our sample, the respondents came from different continents. The largest number of tourists in our sample came from Asian countries (37\%), including China, Japan, South Korea, India, Singapore and Vietnam (TAT, 2010). The percentages of tourists from Africa, the Americas and Europe were $17 \%, 16 \%$ and $16 \%$, respectively. The rest of the tourists in our sample came from Australia (5\%) and Oceania (9\%). 
The demographic data show that 30\% of the tourists (highest) were 26-33 years old. This age range consisted of new graduates just about to enter the workforce, people with a few years of work experience and startup entrepreneurs. The second highest (29.5\%) age group comprised 34-41 yearolds and this more mature age group consisted of people with more work experience and people who were successful in managing their businesses. The third highest group (22\%) comprised 18-25 yearolds. This age group of tourists travelled for leisure and they were either with families/friends or travelling alone. The fourth (14\%) and fifth (4.5\%) age groups comprised $42-49$ year-olds and more than 50 year-olds, respectively.

Surprisingly, approximately $28.5 \%$ of tourists who chose to visit Thailand belonged to the group with the lowest salary range per calendar month (i.e. less than USD 1,000). This lowest salary group was linked to the highest percentage of tourists (30\%) in our sample, who were in the age group of 2633 years. The tourists within this particular age and salary group intended to visit Thailand because the country offers low prices, high customer satisfaction and beautiful shopping and outdoor attractions. The second-lowest salary group consisted of $28 \%$ of the sample population. Nearly $20 \%$ of our sample population had an average salary per calendar month of USD 2000-2999. 5\% of tourists in our sample had an average monthly salary of UDS4000-4999; and 6.5\% of the sample population received an average monthly salary above USD 5000.

\subsection{Descriptive statistics and factor analysis}

In order to identify and explore the underlying factors influencing tourists' intentions to visit Thailand, we conducted exploratory factor analysis. We applied Varimax rotation based on an analysis of the Eigen values greater than 1 with item loadings of at least 0.4 (Hair, Black, Babin, Anderson \& Tatham, 2006). We aimed to determine the appropriate number of factors that influence tourists' decisions (intention) to visit Thailand. Table 1 outlines the results of the factor analysis used to test the factors influencing tourists’ decisions (intention) to visit Thailand.

Table 1: Factor analysis to test the factors influencing customers' online purchase

\begin{tabular}{|l|l|l|l|l|l|}
\hline & Loadings & $\begin{array}{l}\text { \% of variance } \\
\text { explained }\end{array}$ & $\begin{array}{l}\text { Cronbach } \\
\text { alpha }\end{array}$ & Mean & $\begin{array}{l}\text { Standard } \\
\text { deviation }\end{array}$ \\
\hline Service characteristics & & $68.517 \%$ & 0.767 & & \\
\hline SC1-PLAC & & & & & \\
\hline SC2-HERI & 0.725 & & & 3.71 & 1.103 \\
\hline SC3-ARCH & 0.883 & & & 3.29 & 1.060 \\
\hline Basic service expectations & 0.867 & & & 3.25 & 1.174 \\
\hline BSE1-SHOP & & $46.135 \%$ & 0.706 & & \\
\hline BSE2-GREE & 0.697 & & & 3.45 & 1.175 \\
\hline BSE3-CLIM & 0.729 & & & 3.67 & 1.068 \\
\hline
\end{tabular}




\begin{tabular}{|c|c|c|c|c|c|}
\hline BSE4-ACCO & 0.648 & & & 3.65 & 1.013 \\
\hline BSE5-PRIC & 0.707 & & & 3.42 & 1.133 \\
\hline $\begin{array}{l}\text { Personalised service } \\
\text { expectations }\end{array}$ & & $61.003 \%$ & 0.680 & & \\
\hline PSE1-ADAC & 0.786 & & & 3.53 & 1.006 \\
\hline PSE2-SPAC & 0.765 & & & 3.26 & 1.041 \\
\hline PSE3-NTLF & 0.792 & & & 3.67 & 1.019 \\
\hline Social attributes & & $43.556 \%$ & 0.671 & & \\
\hline SA1-PROM & 0.712 & & & 3.21 & 1.076 \\
\hline SA2-DEIM & 0.733 & & & 3.63 & 0.900 \\
\hline SA3-SAFE & 0.637 & & & 3.28 & 1.083 \\
\hline SA4-SERV & 0.677 & & & 3.63 & 1.011 \\
\hline SA5-STAB & 0.519 & & & 2.62 & 1.107 \\
\hline e-advert & & $52.624 \%$ & 0.698 & & \\
\hline Online adverts & 0.712 & & & 3.25 & 0.987 \\
\hline Usefulness & 0.769 & & & 3.41 & 1.164 \\
\hline Trusted websites & 0.758 & & & 3.17 & 1.095 \\
\hline Clear audio-video & 0.658 & & & 3.53 & 1.095 \\
\hline \multicolumn{6}{|l|}{ e-information } \\
\hline Online search info & 0.742 & $51.131 \%$ & 0.678 & 3.76 & 1.177 \\
\hline Tourism info & 0.779 & & & 3.63 & 1.050 \\
\hline Uploaded photos & 0.727 & & & 3.70 & 1.034 \\
\hline Exchange ideas & 0.599 & & & 3.68 & 1.032 \\
\hline e-safety and security & & 50.966 & 0.518 & & \\
\hline Web Links & 0.711 & & & 3.37 & 1.050 \\
\hline Fast services & 0.674 & & & 3.61 & 1.131 \\
\hline News updates & 0.755 & & & 3.81 & 0.895 \\
\hline
\end{tabular}

Based on the test-rotated component matrix, four factors are identified. These four factors represent four different categories; these are service characteristics, basic service expectations, personalised service expectations and social attributes. Although some of these are identified as influential factors in the literature, no classification has been compiled by any particular researchers. All four factors with related variables, along with mean and standard deviation, are listed in Table 1. Cronbach's alpha above 0.6 represents high reliability. All the factors, except for 'price and comfort', prove high levels of reliability. In Table 1 , the items with high loading values can be considered influential factors that can persuade tourists' decisions (intention) for visiting Thailand.

To decide further analysis with e-safety, we tested the reliability of e-safety using composite reliability calculation, which has shown a high value of 0.757 and, hence, e-safety is considered reliable (see Table 2). 
Table 2: Correlation and composite reliability of factors

\begin{tabular}{|l|l|l|l|l|l|l|l|}
\hline & 1 & 2 & 3 & 4 & 5 & 6 & 7 \\
\hline $\begin{array}{l}\text { Service } \\
\text { characteristics }\end{array}$ & $\mathbf{0 . 8 6 7}$ & & & & & & \\
\hline $\begin{array}{l}\text { Basic service } \\
\text { expectations }\end{array}$ & 0.501 & $\mathbf{0 . 8 1 0}$ & & & & & \\
\hline $\begin{array}{l}\text { Personalized } \\
\text { service expectations }\end{array}$ & 0.356 & 0.446 & $\mathbf{0 . 8 2 4}$ & & & & \\
\hline Social attributes & 0.489 & 0.570 & 0.542 & $\mathbf{0 . 7 9 1}$ & & & \\
\hline e-advert & 0.349 & 0.349 & 0.259 & 0.319 & $\mathbf{0 . 8 1 2}$ & & \\
\hline e-info & 0.374 & 0.508 & 0.251 & 0.345 & 0.461 & $\mathbf{0 . 8 0 6}$ & \\
\hline $\begin{array}{l}\text { e-safety and } \\
\text { security }\end{array}$ & 0.380 & 0.524 & 0.330 & 0.386 & 0.268 & 0.403 & $\mathbf{0 . 7 5 7}$ \\
\hline Note: Diagonal elements represent composite reliability of constructs. & & \\
\hline
\end{tabular}

From Table 2, we see that each construct is discriminant from other constructs as correlations among these constructs are very low. This proves the discriminant validity of the data (Hair et al., 2006; Cronbach and Meehl, 1955). Further, the diagonal elements represent the composite reliability values. All of them are above 0.7 and between 0.757 and 0.867 , which reassures the reliability of the data collected for this study.

\section{Analysis and results}

In this research, we have used a two-stage approach to test the models (Anderson \& Gerbing, 1988). In the first stage, we developed measurement models using confirmatory factor analysis. In the second stage, we used structural equation modelling (SEM) to test the hypothesized structural relationships in the conceptual model (see Figure 1). In both stages, we have used standard commonly available fit indices, as suggested in the literature, to assess the validity of the models (Hair et al., 2006). We used AMOS 19 and SPSS 19 for our data analysis. In this analysis, we have employed some of the commonly-used indices in SEM; namely, Chi-square $\left(\chi^{2}\right)$, degree of freedom, normed Chi-square, comparative fit index (CFI), Tucker Lewis index (TLI), root mean square error approximation (RMSEA) and p-value. In order to develop structural models in line with the hypothesized model, we have developed measurement models with first-order and second-order variables.

\subsection{Measurement models}

In developing our measurement model, we use the four identified factors that potentially influence customers' trust online. The factors namely, destination characteristics, service expectations, price and comfort, have shown significant loadings with all their respective measured items (see Table 1). In the first measurement model, we establish covariance relationships among all the four constructs of service characteristics, basic service expectations, personalised service expectations and social 
attributes. The model fit exceeds the recommended minimum (Hair et al., 2006). Normed Chi-square is 1.439 with significant $\mathrm{p}<0.003$. CFI also proves a good fit of this model with a value of 0.945 . The correlations among the first-order factors show significant positive values representing the purpose of visiting Thailand.

According to our hypothesised conceptual framework, tourists' e-trust is motivated by four key factors, which are service characteristics, basic service expectations, personalised service expectation and social attributes. Hence, we use these factors to measure the second-order latent construct 'e-trust'. Our second-order model shows a good fit index with $\mathrm{p}<0.002$ (CFI=0.942; TLI=0.922 and RMSEA=0.047). Factor loading between the constructs 'service characteristics' and 'e-trust' is significant with a positive loading of 0.65 and $\mathrm{R}^{2}=0.417$. This proves our first research hypothesis (H1) that the unique service characteristics influence online purchase intention positively. A positive loading ( 0.97 with $\mathrm{R}^{2}=0.761$ ) between the constructs ‘service expectations' and 'e-trust' expresses the validity of our second hypothesis (H2) that tourists' service expectations directly favour their intentions to purchase online. The link between the constructs 'intention' and 'personalised service expectations' also shows a significant positive loading of 0.79 with $\mathrm{R}^{2}=0.618$. Similarly, the other link from 'intention' and 'social attributes' shows a significant loading of 0.87 with $\mathrm{R}^{2}=0.94$, which proves $\mathrm{H} 3$ and H4.

\subsection{Structural model}

As both measurement models proved to be the best fit, we further test our conceptual framework through structural equation modelling. In stage 2, we develop structural models to test our conceptual framework on e-trust. The second-order model is developed into a structural model by adding a new construct, 'satisfaction'. Nowadays, almost all business sectors try and retain customers by providing satisfactory goods and services. In this research, survey respondents were tourists who were already on their visit to the country (Thailand). They cited four main reasons for their visit (second-order measurement model). These tourists felt satisfied with the extent to which their initial expectations of the visit are fulfilled. We aim to test this relationship between 'e-trust' and 'satisfaction' through structural equation modelling by combining all the variables discussed in the measurement models. We measure satisfaction in terms of tourists' intention to repeat their visit and of recommendation to their families and friends. Both these measured items 'visit again' and 'recommend' have shown significant loading values of 0.84 and 0.60 , respectively. The path coefficient (0.52) between the constructs 'intention to visit Thailand' and 'satisfaction' is significant. The fit indices of this model show its superiority with high CFI 0.946, low RMSEA 0.042 and normed Chi-square 1.361 with $p<0.004$. This perfect model fit confirms our research hypothesis (H5) that tourists visiting Thailand will be satisfied by their visits. 


\subsection{Mediation effect of the Internet on e-trust and customer satisfaction}

The service industry, specifically the tourism sector, is heavily influenced by internet advertising and online booking. Our literature review in section 2 reports the impact of internet advertisements, web information and internet safety in choosing holiday destinations. We test the influence of three constructs - e-advert, e-information and e-security - in customer satisfaction. The mediating role of each of these three constructs is tested in the relationship between intention to visit and satisfaction.

First, we develop a structural equation model with the mediating variable 'e-advert'. This model shows a perfect fit with suggested indices CFI $=0.912$, normed Chi-square 1.463, and RMSEA 0.048. However, the path between intention to visit and satisfaction in this model has become insignificant as an effect of mediation. This proves the mediating role of e-advert in customer satisfaction (H6).

Similarly, we test the role of mediation in the relationship between intention to visit and satisfaction for e-information and e-security. In both cases, the model fit is well under the suggested level. As expected, these two variables - e-information and e-security - have insignificant coefficient values, which can be interpreted in such a way that both e-information and e-security mediate the relationship between tourists' visit and satisfaction. This argument proves our next two hypotheses that e-information and e-safety mediate the relationship between visit and satisfaction (H7 and H8). This finding can be related to the age and income levels of visitors. The age structure of respondents tends to be young adult individual travellers who are more likely to be heavy internet users. These customers may not follow a simplistic, deterministic information search process in which they consult sources before travel and evaluate the vacation at the end of travel. Rather, supported by online sources, they may follow a less structured, continuous information search process that begins before travel and is maintained throughout the vacation. Expectations are therefore not only formed before the purchase but may be adjusted throughout the travel process based on the available information. Since expectations are continuously formed and any mismatch in expectation and perceived service will result in dissatisfaction, tourism operators must upload recent information on the website to maintain quality information for potential tourists.

The e-security finding can also be linked to age and the respondent's country of origin. In this study, most visitors are from emerging markets and may have lower per-capita incomes than customers from more developed countries. Vacation travel is a high-involvement transaction for most customers, particularly in this case where respondents have less income to dedicate to leisure activities. Further, emerging markets tend to have lower levels of regulative institutions and enforcement (Luo \& Peng, 1999). Consequently, purchasing actions can be more difficult and legal regulation for failure to supply is weak or inadequately enforced (Khanna \& Rivkin, 2001). The e-safety features, such as the presence of valid third-party mechanisms, can help potential users establish institution-based trust in online platforms (Iglesias-Pradas et al., 2013). This enables customers to trust the recommendations of these 
sites and, if expectations are met, they will be satisfied with their vacation. Fit indices of all the above models are given in Table 3.

Table 3: Fit indices of models

\begin{tabular}{|l|l|l|l|l|l|l|}
\hline Models & $\chi^{\mathbf{2}(d f)}$ & $\begin{array}{l}\text { Normed } \\
\text { chi-square }\end{array}$ & CFI & TLI & $\begin{array}{l}\text { RMSEA (90\% } \\
\text { CI) }\end{array}$ & p-value \\
\hline $\begin{array}{l}\text { Measurement } \\
\text { model } \\
\text { (Figure 2) }\end{array}$ & $\begin{array}{l}142.439 \\
(99)\end{array}$ & 1.439 & 0.945 & 0.924 & $\begin{array}{l}0.047 \\
(0.028,0.063)\end{array}$ & 0.003 \\
\hline $\begin{array}{l}\text { Second-order } \\
\text { model } \\
\text { (Figure 3) }\end{array}$ & $\begin{array}{l}146.689 \\
(101)\end{array}$ & 1.452 & 0.942 & 0.922 & $\begin{array}{l}0.047 \\
(0.029,0.064)\end{array}$ & 0.002 \\
\hline $\begin{array}{l}\text { Structural model } \\
\text { - direct model } \\
\text { (Figure 4) }\end{array}$ & $\begin{array}{l}178.242 \\
(131)\end{array}$ & 1.361 & 0.946 & 0.930 & $\begin{array}{l}0.042 \\
(0.025,0.057)\end{array}$ & 0.004 \\
\hline $\begin{array}{l}\text { Mediation } \\
\text { model-e-advert } \\
\text { (Figure 5a) }\end{array}$ & $\begin{array}{l}298.350 \\
(204)\end{array}$ & 1.463 & 0.912 & 0.890 & $\begin{array}{l}0.048 \\
(0.036,0.059)\end{array}$ & 0.000 \\
\hline $\begin{array}{l}\text { Mediation } \\
\text { model-e-info } \\
\text { (Figure 5b) }\end{array}$ & $\begin{array}{l}305.245 \\
(204)\end{array}$ & 1.496 & 0.907 & 0.885 & $\begin{array}{l}0.050(0.038,0.06 \\
1)\end{array}$ & 0.000 \\
\hline $\begin{array}{l}\text { Mediation } \\
\text { model-e-safety } \\
\text { (Figure 5c) }\end{array}$ & $\begin{array}{l}254.708 \\
(184)\end{array}$ & 1.384 & 0.929 & 0.911 & $0.044(0.030, .056)$ & 0.000 \\
\hline
\end{tabular}

Figure 2: Measurement model

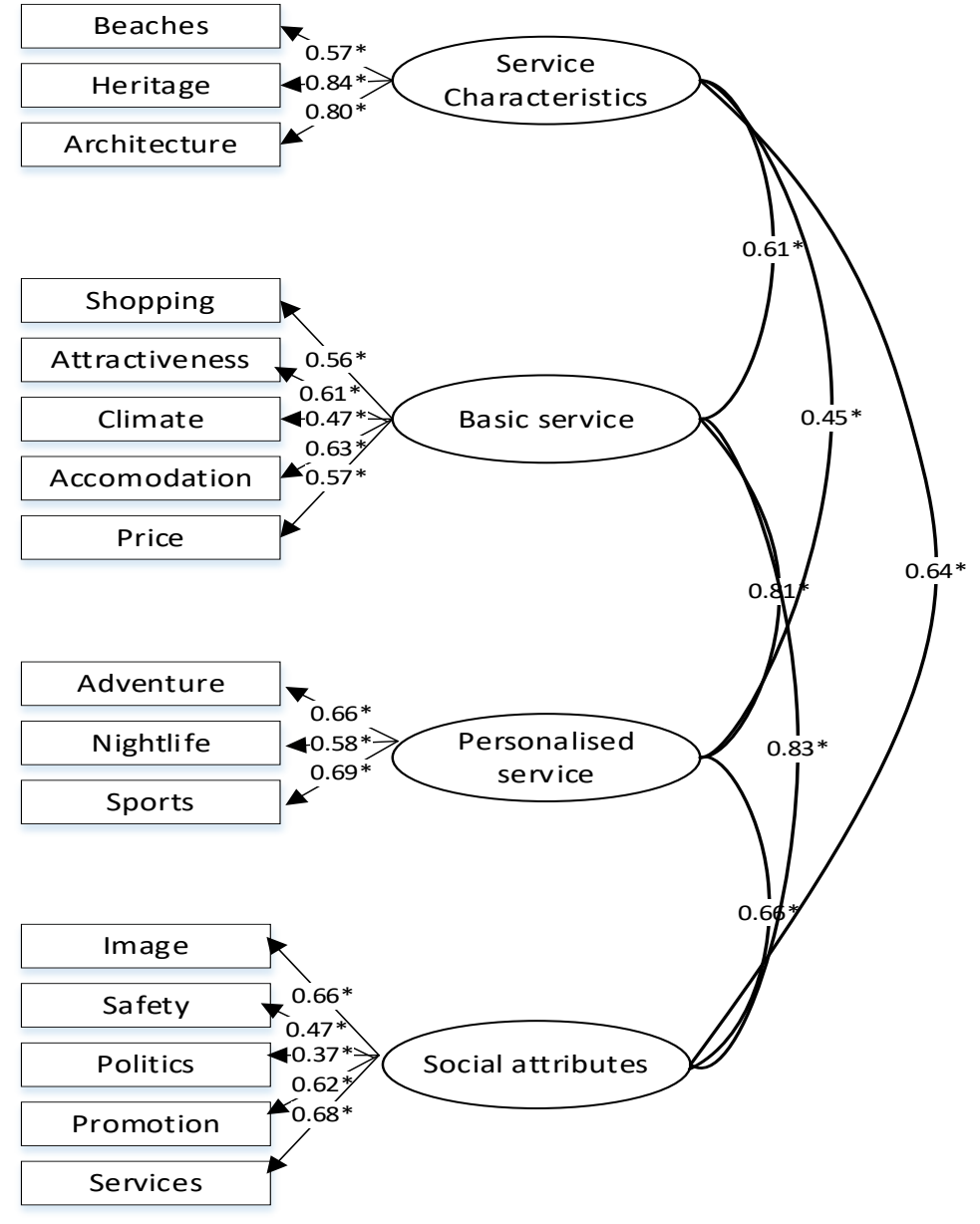

* significance $p<0.05$ 
Figure 3: Second-order model

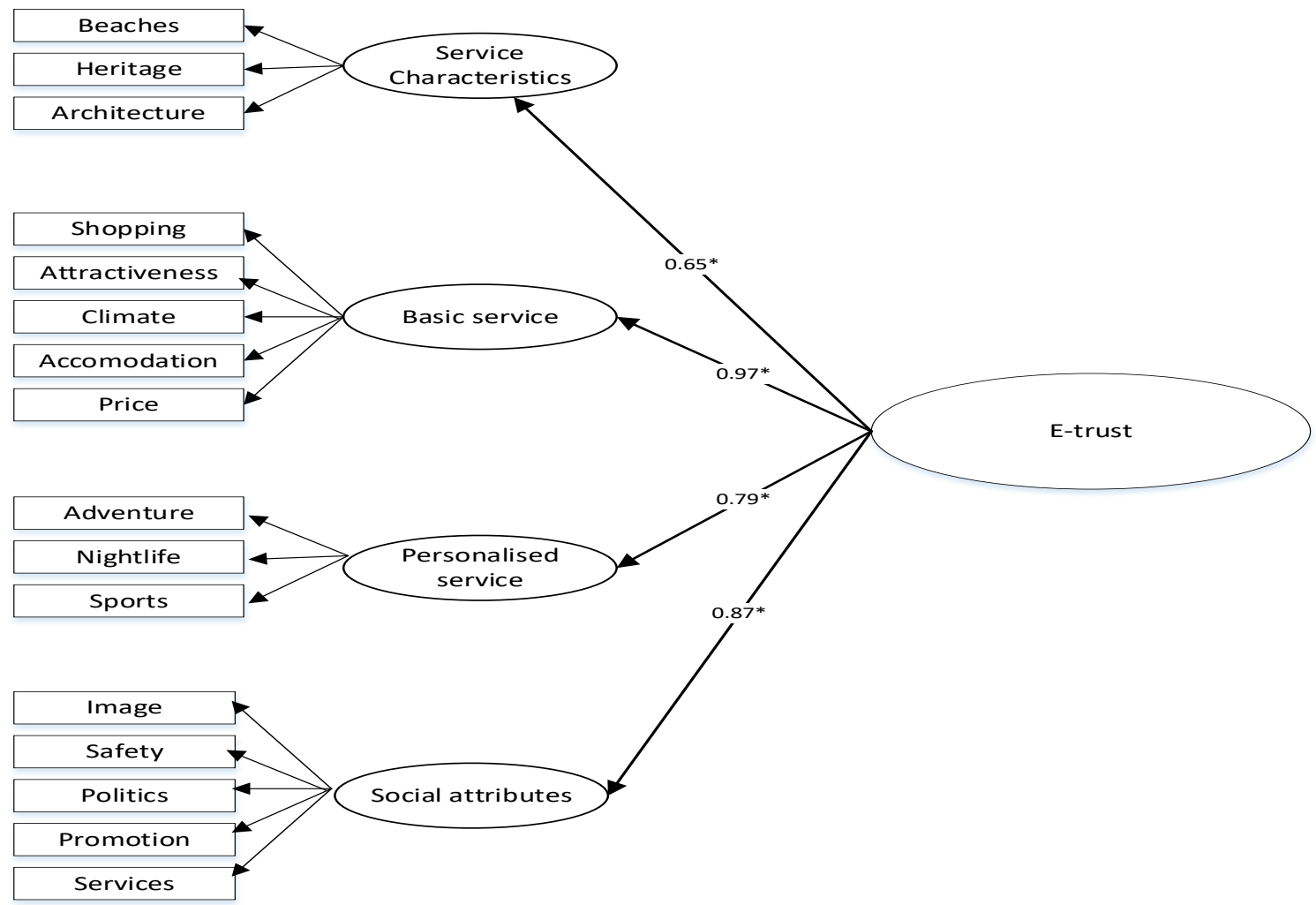

Figure 4: Structural model

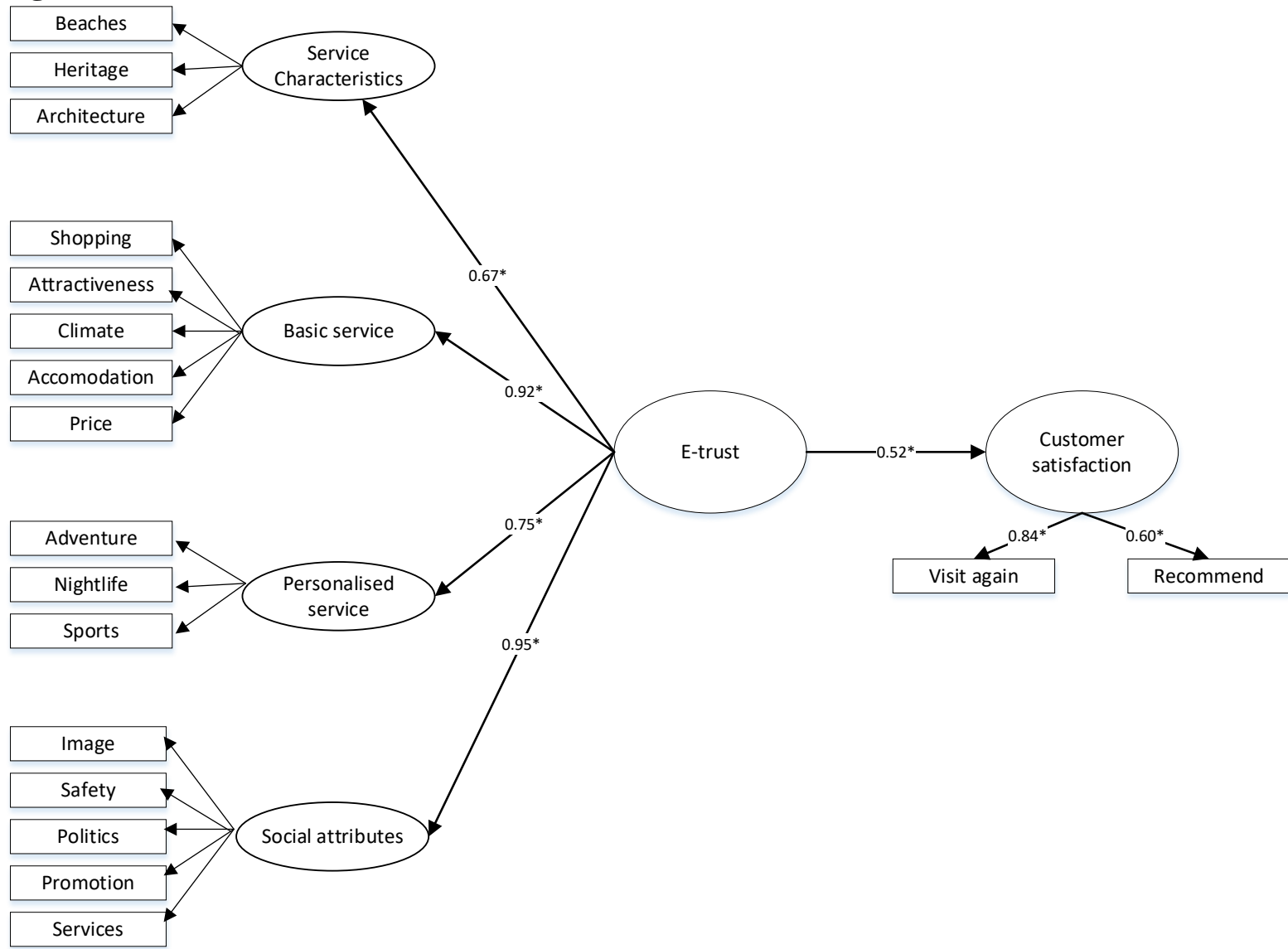


Figure 5a: Mediation effect of e-advert.

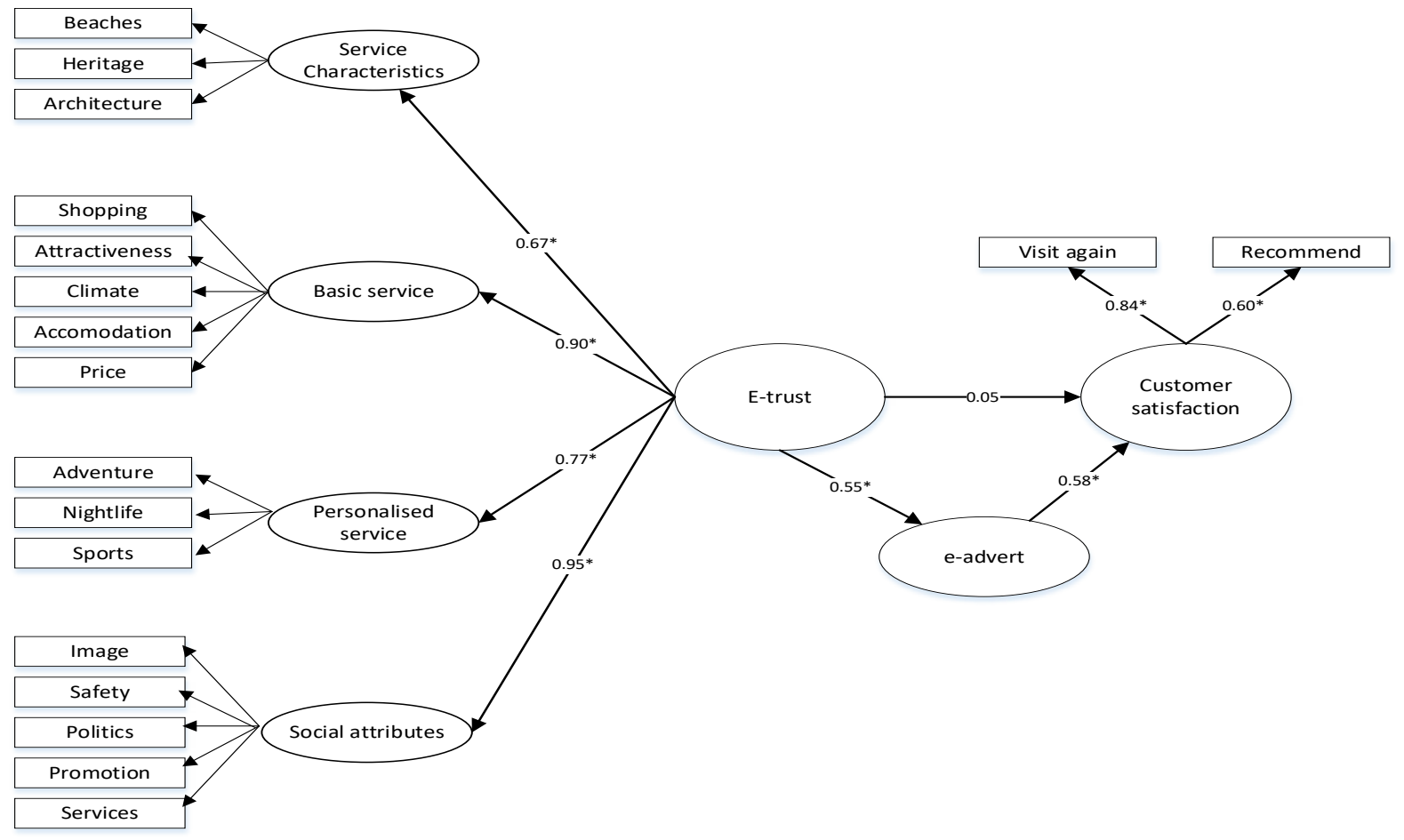

Figure 5b: Mediation effect of e-information

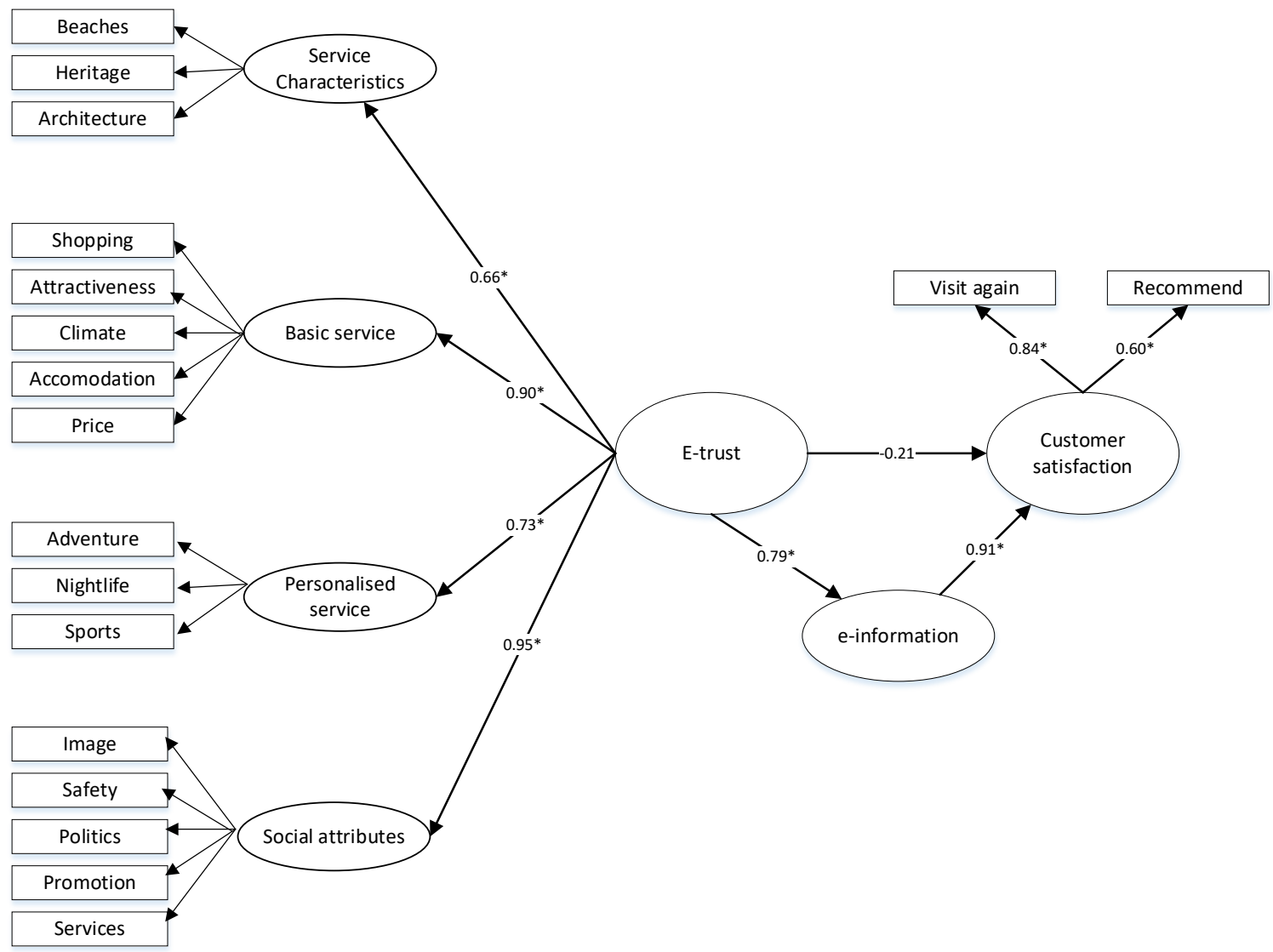


Figure 5c: Mediation effect of e-safety

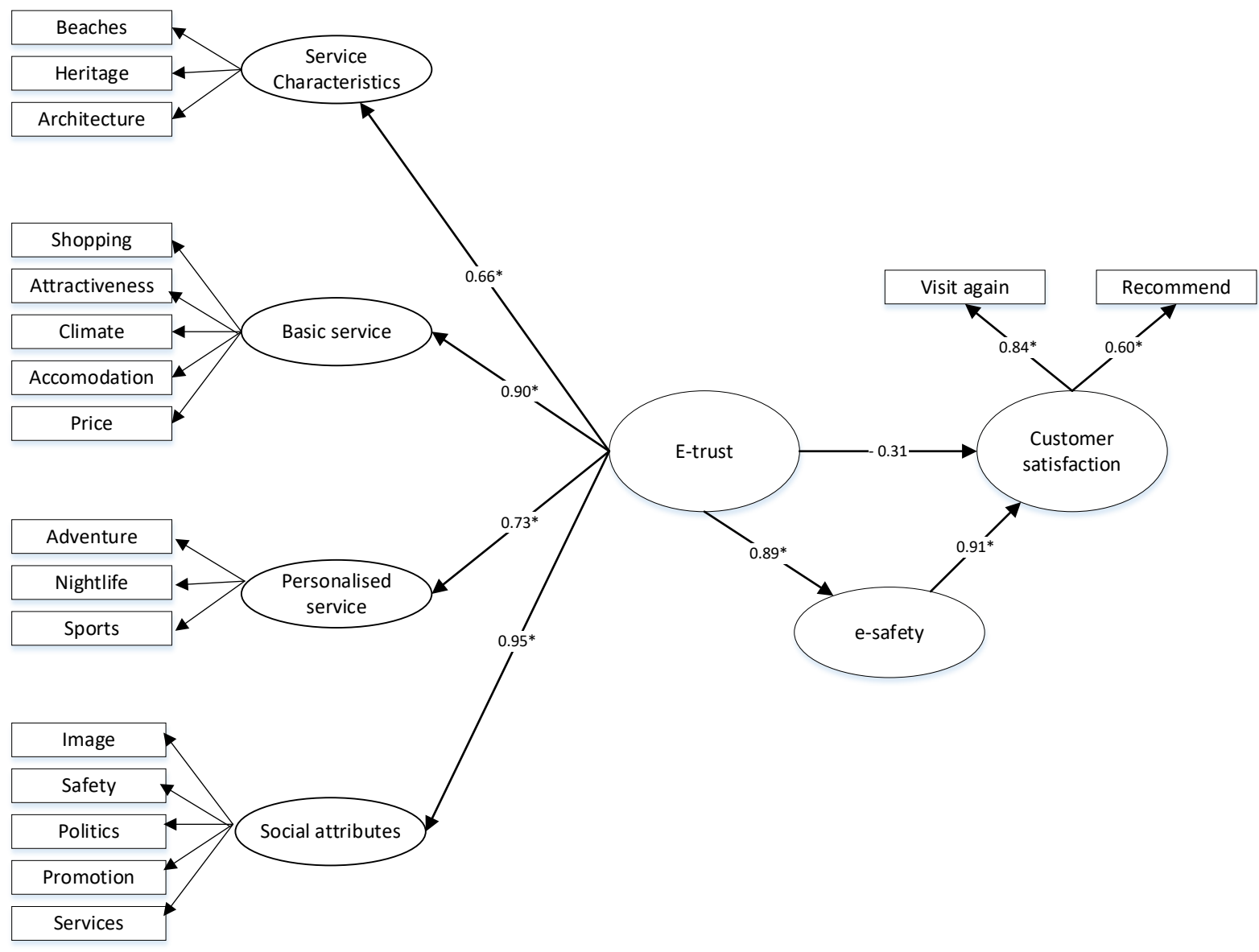

\section{Further discussions and managerial implications}

We have examined the relationship between customers' purchase intentions and the status of etrust of the online service providers, using Thailand tourism as a case in point. By investigating the factors related to the tourism industry, we find that tourists' e-trust is based on internet factors, such as advertisement, trust, and internet reviews (Ramanathan, 2011; Ramanathan et al., 2012). In particular, internet advertising and e-commerce can be used to persuade buyers (Armstrong, 1997; Ramanathan et al., 2012). Our results show that the influence of social media (internet advertising) is significantly mediating the relationship between purchase intention and satisfaction. Information provided through social media platforms reduces information asymmetries which helps customers to develop trust with online sites (Meyer et al., 2009). Additionally, innovation diffusion in businesses and society happens via social media platforms in recent years (Peng and Vlas, 2017) which develops customers' expectations and future demand. In other words, customers have expectations based on social media advertisements, which will ultimately influence their actual satisfaction after purchase. Satisfied customers tend to use the service again and also recommend the service through social media, which 
increases the trustworthiness of the online seller (Gefen \& Reychav, 2014). This research sends a valuable message across the service industry on the need for frequent information updates in service providers' webpages and social media to attract and retain customers. Moreover, it is vital to maintain e-safety to gain customers' trust. Satisfied customers consider the online site as trustworthy by recommending it to their friends and families. This will help future business outcomes of the service companies.

Availability of online information on service provisions, such as local attractions, money exchange, accommodation and other useful information, will attract potential customers. Although tourists' satisfaction can be achieved through different factors, the most important factor affecting internet users' satisfaction is information. The information provided through internet advertising must be carefully studied as it can influence customers' behaviour in repeated browsing of online information. As internet advertising and customer reviews can directly influence tourists' behaviour and the service industry more generally, all service industries, particularly the tourism industry, should produce quality internet advertising and acquire positive reviews to influence e-trust.

The advantages of online purchases are the direct and quick communication links set up via the internet between the service industry (travel companies) and users (tourists). However, online customers lack interpersonal interaction with the online service provider and, therefore, may feel vulnerable in making purchase decisions. Vulnerability requires trust in social and business relationships (Blau, 1964; Mayer et al., 1995). It is important to maintain a safe platform for customers to make payment and to access the necessary security details. The increase in online customers who rely on the internet and social media to search information related to choice of services, issues associated with e-security, privacy risks and customer satisfaction reviews have become major influencing factors on potential customers' trust online (Hofacker \& Murphy, 2000; McCole et al., 2010; Park et al., 2013; Ramanathan, 2011). This e-safety measure can help to satisfy customers and ensure retention of loyal customers, as trustworthy sellers are more likely to be revisited and used by customers (Gefen \& Reychav, 2014; Li et al., 2012). As suggested by Nyaga, Whipple and Lynch (2010), only trusted relationships can enhance customer satisfaction. Offering comfortable e-safety and providing reliable information through online media can win over customers' trust and, hence, their satisfaction.

\section{Conclusions}

Social media and internet advertising are important tools that can help organisations achieve their performance goals and gain a competitive advantage over their rivals. Different and innovative business analytics approaches can help organisations use available data effectively to grow their businesses (Ranyard, Fildes \& Hu, 2015). All sectors (private, public and government) are using social media to reduce the costs of promoting their products or services. This research suggests that the service industry needs to ensure e-safety and security to sustain e-commerce success (McCole et al., 2010; Park et al., 2013). Business analytics can help top management to understand the market and customers' 
choices. Customers' concerns over privacy and safety require service providers (businesses) to ensure that personal and financial information is secure. Online offerings need to win over customers' trust, assuring them that purchasing and other risks are minimised or mitigated (McCole et al., 2010). Service operators maintaining these online purchase mechanisms need to communicate e-safety information and adopt recognized security standards clearly or customers may hesitate to make payments online.

Because customers' expectations are being formed by online promotion, it is necessary to ensure that the actual experiences match the virtual images promoted. As the power of internet advertising and reviews can influence online customers' intention in purchasing products or services (Hunter, 2016), internet advertising needs to have production values that communicate required information in a way that online purchasers can understand. These high-quality productions will work alongside emergent, bottom-up customer reviews to build an online TDI that is authentic and attractive. It is recommended that internet service providers adopt the idea of web analytics $\mathrm{A} / \mathrm{B}$ testing from the IT world, in which several versions are developed and tested online before launch.

Our research findings provide a new perspective on e-commerce use in the service sector, where e-safety and e-trust are considered the most important aspects of customer satisfaction. This result sends a strong message to top management on the need to maintain safety assurance for online customers. In this era of social media, e-safety faces constant challenges and, hence, service providers need to ensure a safe environment for customers when they use online information and online cash-payment options. A practical implication for the service industry is to consider investing in e-safety as a key competitive advantage. As social media is the main source of information for online purchasers, the quality of the information in websites and social media attracts potential buyers from different age and income groups. Future research can include a detailed study on the role of age and income in identifying the role of various social media types in customers' online purchase experiences and levels of trust and satisfaction. Similar studies can also be conducted in other industries and emerging markets.

As the main focus of our research is the roles of online advertising, e-safety, e-trust, and e-security and their impact on the success of the service sector (e.g., customer satisfaction), we have identified the specific literature in this area. As the B2C service sector covers a broad spectrum of businesses, we focus on models related to customer purchases in online or social media platforms and position our research based on Gefen and Reychav's (2014) model of trustworthiness of online sales. The authors used a case of IT vendors and the feedback they received on their performance to establish the concept of trustworthiness. Interestingly the authors related the users' communication with managers and their perception of success to IT projects. Additionally, they related the acceptance of the IT project's objectives positively to the perceived success of the project. The prime message from this model is that the purchase intention of online customers is influenced by e-trust. Gefen and Straub (2004) created a four-dimensional scale for e-trust, incorporating integrity, predictability, ability, and benevolence. In this paper, we set out to extend this e-trust to a service sector (tourism) operating through online 
platforms. Gefen's (2000) initial model established a direct link between trust and purchase whereas his later models extended the concept and established a link between e-trust and purchase intentions. In line with this, we also consider Kim et al.'s (2008) support for the positive influence of trust on consumers' purchase decisions. Gefen and Reychav (2014) included the concept of trustworthiness in achieving the online presence and success of IT projects. Accordingly, we consider the actual purchase activity online as a representation of trust and the customer's future purchase and recommendations as a long-term relationship between the online service provider and the customer, which is a traditional view of trustworthiness. Our research specifies the importance of developing online trust in order to achieve customer satisfaction.

\section{Limitations and future research}

In comparison with the concept of trust, which is regarded as a psychological state, trustworthiness is a behavioural manifestation of trusting relationships. Greenwood and Van Buren III (2010, p.430) note that trustworthiness is regarded as a person's disposition and motivation and organisational trustworthiness, therefore, refers to "a virtue or set of virtues held by the organisation, reflecting its worthiness to be trusted”. We concur with Gefen and Straub (2004) that trustworthiness is more critical a concept and variable to investigate for e-trust as it manifests the predictability of online purchasing behaviour. Caldwell and Clapham (2003) contended that trustworthiness is the antecedent of accumulated perceptual experiences and this will help to build trust. In online transactions, customers will only be satisfied with the service provider if the online platform maintains as a trustworthy business through continuous interaction between the two parties. Therefore, we propose that future research needs to focus on e-trustworthiness. A methodological implication of this proposal is the need to collect longitudinal data, rather cross-sectional data, to reflect the behavioural dimension of online purchasing.

Our study has a limitation in data from respondents limited to one industry. Future research can consider several industries to conduct research on e-trust and related factors. In addition to broadening the empirical perspective, future research to develop theory in e-trust can also adopt methods that examine causal effects, such as experimental designs (Fong, Law, Tang \& Yap, 2016). Experimental and quasi-experimental designs enable examination of the impact of the presence or absence of factors on a given outcome. More recently, the development of online virtual experiment platforms allows researchers to examine psychological phemonena (Anwyl-Irvine, Massonnié, Flitton, Kirkham \& Evershed, 2019). They provide the benefit of external validity like field experiments, along with control over factors and variables that cannot be obtained in a real world setting (Palan \& Schitter, 2018). A possible design may examine the presence or absence of website or e-commerce platform features that may provide signals to potential visitors. Over the next decade, more and more sales will happen online and it is important to secure customers' e-trust to survive in the market. 


\section{References}

Anderson, J.C., \& Gerbing, D.W. (1988). Structural equation modelling in practice: a review and recommended two-step approach. Psychological Bulletin, 103(3), 411-423.

Anwyl-Irvine, A. L., Massonnié, J., Flitton, A., Kirkham, N., \& Evershed, J. K. (2019). Gorilla in our Midst: An online behavioral experiment builder. Behavior research methods, 1-20.

Armstrong, S. (1997). Advertising on the Internet. London: Kogan Page Limited.

Artigas, E. M., Yrigoyen, C. C., Moraga, E. T., \& Villalón, C. B. (2017). Determinants of trust towards tourist destinations. Journal of Destination Marketing \& Management, 6(4), 327-334.

Baloglu, S., \& Brinberg, D. (1997). Affective images of tourism destinations. Journal of Travel Research, 35, 11-15.

Bigne, J., Sanchez, M., \& Sanchez, J. (2001). Tourism image, evaluation variables and after purchase behavior: Inter-relationships. Tourism Management, 22, 607-616.

Blau, P. (1964). Exchange and Power in Social Life. New York: John Wiley.

Caldwell, C., \& Clapham, S. (2003). Organizational trustworthiness: An international perspective. Journal of Business Ethics, 47, 349-364.

Chua, R., Morris, M., \& Ingram, P. (2009). Guanxi vs networking: Distinctive configurations of affectand cognition-based trust in the networks of Chinese vs American managers. Journal of International Business Studies, 40, 490-508.

Cronbach, L. J., \& Meehl, P. E. (1955). Construct validity in psychological tests. Psychological Bulletin, 52, 281-302.

Das, T., \& Teng, B. (1998). Between trust and control: Developing confidence in partner cooperation in alliances. Academy of Management Review, 23, 491-512.

Davis, F. D., Bagozzi, R. P., \& Warshaw, P. R. (1989). User acceptance of computer

technology: A comparison of two theoretical models. Management Science, 35,

982-1003.

Echtner,C. M., \& Ritchie, J.R.B. (1993), The Measurement of Destination Image: An Empirical Assessment. Journal of Travel Research, 31(4), 3-13.

Filieri, R., Alguezaui, S., \& McLeay, F. (2015). Why do travelers trust TripAdvisor? Antecedents of trust towards consumer-generated media and its influence on recommendation adoption and word of mouth. Tourism Management, 51, 174-185.

Fesenmaier, D. R., \& Jeng J. (2000). Assessing structure in the pleasure trip planning process. Tourism Analysis, 5(1), 13-27.

Fong, L. H. N., Law, R., Tang, C. M. F., \& Yap, M. H. T. (2016). Experimental research in hospitality and tourism: a critical review. International Journal of Contemporary Hospitality Management, 28(2), 246-266.

Gallarza, M. G., Saura, I. C., \& García, H. C. (2001). Measuring destination image an approach by an attribute-based analysis. Tourism Review, 56(1/2), 13-22.

Gefen, (2000). E-commerce: the role of familiarity and trust. Omega: the International Journal of Management Science, 28, 725-737

Gefen , D., \& Reychav, I. (2014). Why trustworthiness in an IT vendor is important even after the vendor left: IT is accepting the message and not just the messenger that is important. Omega: the International Journal of Management Science, 44, 111-125.

Gefen, D., \& Straub, D.W. (2004). Consumer Trust in B2C e-commerce and the importance of social presence: experiments in e-Products and e-Services. Omega: the International Journal of Management Science, 32, 407-424.

Greenwood, M., \& Van Buren III, H. (2010). Trustworthiness in the Organization-Stakeholder Relationship. Journal of Business Ethics, 95, 425-438.

Hair, J.F., Black, W.C., Babin, B.J., Anderson, R.E., \& Tatham, R.L. (2006). Multivariate Data Analysis. 6th edn. New Jersey: Prentice-Hall.

Hernández, B., Jiménez, J.,\& Martín, J.M. (2010) Customer behavior in electronic commerce: The moderating effect of e-purchasing experience. Journal of Business Research, 63, 964-971.

Hofacker, C. F., \& Murphy, J. (2000). Clickable world wide web banner ads and content sites. Journal of Interactive Marketing, 14(1), 49-59.

Holloway, C.J. (2006). The business of tourism, 7th edn. Essex: Pearson Education Limited. 
Hsieh, T.A., \& Chang, J. (2006). Shopping and tourist night markets in Taiwan, Tourism Management, 27(1), 138-145.

Hui, T.K., \& Wan, D. (2007). Factor affecting Internet shopping behavior in Singapore gender and educational issues. International Journal of Consumer Studies, 31(3), 310-316.

Hunter, W.C. (2016). The social construction of tourism online destination image: A comparative semiotic analysis of the visual representation of Seoul. Tourism Management, 54, 221-229.

Hyde, K. F. (2007). Contemporary information search strategies of destination-naïve international vacationers. Journal of Travel \& Tourism Marketing, 21(2-3), 63-76.

Hudson, S., \& Thal, K. (2013). The impact of social media on the consumer decision process: Implications for tourism marketing. Journal of Travel \& Tourism Marketing, 30(1-2), 156-160.

Iglesias-Pradas, S., Pascual-Miguel, F., HernáNdez-GarcíA, Á., \& Chaparro-PeláEz, J. (2013). Barriers and drivers for non-shoppers in B2C e-commerce: A latent class exploratory analysis. Computers in Human Behavior, 29(2), 314-322.

Igbaria, M., Schiffman, S.J., Wieckowski, T.J. (1994). The respective roles of perceived usefulness and perceived fun in the acceptance of microcomputer technology. Behaviour and Information Technology,. 13, 349-361.

Internet World Stats. (2011). The Internet big picture. Available at: http://www.internetworldstats.com (accessed on 13 June 2017).

Jenkins, H.O. (1999). Understanding and measuring tourist destination image. International Journal of Tourism Research, 1-15.

Khanna, T., \& Rivkin, J. W. (2001). Estimating the performance effects of business groups in emerging markets. Strategic Management Journal, 22(1), 45-74.

Kim, D.J., Ferrin, D.L., \& Rao, H.R. (2008). A trust-based consumer decision-making model in electronic commerce: The role of trust, perceived risk, and their antecedents. Decision Support Systems, 44, 544-564.

Kim, S. E., Lee, K. Y., Shin, S. I., \& Yang, S. B. (2017). Effects of tourism information quality in social media on destination image formation: The case of Sina Weibo. Information \& Management, 54(6), 687-702.

Kock, F., Josiassen, A., \& Assaf, A. G. (2016). Advancing destination image: The destination content model. Annals of Tourism Research, 61, 28-44.

Kumar, N., \& Kumar, R. R. (2019). Relationship between ICT and international tourism demand: A study of major tourist destinations. Tourism Economics, 1354816619858004.

Lankton, N. K., \& Wilson, E. V. (2007). Antecedents and dimensions of online service expectations. IEEE Transactions on Engineering Management, 54(4), 776-788.

Law, R., Leung, K., \& Wong, J. (2004). The impact of the Internet on travel agencies. International Journal of Contemporary Hospitality Management, 16(2), 100-107.

Leung, D., Law, R., Van Hoof, H., \& Buhalis, D. (2013). Social media in tourism and hospitality: A literature review. Journal of travel \& tourism marketing, 30(1-2), 3-22.

Li, F, Pieńkowski, D., van Moorsel, A., \& Smith, C. (2012). A Holistic Framework for Trust in Online Transactions. International Journal of Management Reviews, 14, 85-103.

Lin, J., \& Chan, H. C. (2008). Understanding the beliefs and intentions in search and purchase functions in an E-commerce web site. IEEE transactions on Engineering Management, 56(1), 106-114.

Luo, Y., \& Peng. M. W. (1999). Learning to compete in a transition economy: Experience, environment and performance. Journal of International Business Studies, 30(2), 269-295.

Maclnnis, D.J., \& Price, L.L. (1987). The role of imagery in information processing: Review and extensions. Journal of Consumer Research,13(4), 473-491.

Martin, H.S., \& Herrero, A. (2012). Influence of the user's psychological factors on the online purchase intention in rural tourism: Integrating innovativeness to the UTAUT framework. Tourism Management, 33(2), 341-352. 
Marinao, E., Chasco, C., \& Torres, E. (2012). Trust in tourist destinations. The role of local inhabitants and institutions. Academia. Revista Latinoamericana de Administración, (51), 27-47.

Mayer, R.C., Davis, J., \& Schoorman, D. (1995). An integrative model of organizational trust. Academy of Management Review, 20, 709-734.

Meyer, K. E., Estrin, S., Bhaumik, S. K., \& Peng, M. W. (2009). Institutions, resources, and entry strategies in emerging economies. Strategic Management Journal, 30(1): 61-80.

McCole, P., Ramsey, E., \& Williams, J. (2010) Trust considerations on attitudes towards online purchasing: The moderating effect of privacy and security concerns. Journal of Business Research, 63, 1018-1024.

Maillet, É., Mathieu, L Sicotte, C. (2015). Modeling factors explaining the acceptance, actual use and satisfaction of nurses using an Electronic Patient Record in acute care settings: An extension of the UTAUT. International Journal of medical informatics. 84(1) 36-47.

Ng, I.S., Lee, A.J., \& Soutar, N.G. (2007). Tourists' intention to visit a country: The impact of cultural distance. Tourism Management, 28(6), 1497-1506.

Nyaga, G.N., Whipple, J.M., \& Lynch, D.F. (2010). Examining supply chain relationships: Do buyer and supplier perspectives on collaborative relationships differ? Journal of Operations Management, 28, 101-114.

Palan, S., \& Schitter, C. (2018). Prolific. ac-A subject pool for online experiments. Journal of Behavioral and Experimental Finance, 17, 22-27.

Park, J., Han, H., \& Park, J. (2013) Psychological antecedents and risk on attitudes toward ecustomization. Journal of Business Research, 66, 2552-2559.

Pearce, G.D., \& Butler, W.R. (1993). Tourism research critiques and challenges. London: Routledge.

Pergelova, A., Prior, D., \& Rialp, J. (2010). Assessing advertising efficiency. Journal of Advertising, 39(3), 39-54.

Peng, M. W., and Vlas, C. O. (2017). Diffusion of a twentieth-century innovation. Academy of Strategic Management Journal, 16(1): 172-174.

Pike, S., \& Ryan, C. (2004). Destination positioning analysis through a comparison of cognitive, affective and conative perceptions. Journal of Travel Research, 42(4), 333-342.

Punyatoya, P. (2019). Effects of cognitive and affective trust on online customer behavior. Marketing Intelligence \& Planning, 37(1), 80-96.

Ramanathan, R. (2011). An empirical analysis on the influence of risk on relationships between handling of product returns and customer loyalty in E-commerce International Journal of Production Economics, 130, 255-261.

Ramanathan, R. (2012). A mathematical programming model for estimating the importance levels of performance criteria and an application in e-commerce. Expert Systems with Applications, 39(2), 2067-2072.

Ramanathan, U., \& Muyldermans, L.( 2010). Identifying demand factors for promotional planning and forecasting: A case of a soft drink company in the UK. International Journal of Production Economics, 128(2), 538-545.

Ramanathan, R., Ramanathan, U., \& Hsiao, H-L (2012), The impact of e-commerce in Taiwanese SMEs: marketing and operations effect. International Journal of Production Economics, 140(2), 934-943.

Ramanathan, U., Subramanian, N., \& Parrott, G. (2017). Role of social media in retail network operations and marketing to enhance customer satisfaction. International Journal of Operations \& Production Management, 37(1), 105-123.

Ranyard, J.C., Fildes, R., \& Hu, T.I. (2015). Reassessing the scope of OR practice: the influences of problem structuring methods and the analytics movement. European Journal of Operational Research, 245(1), 1-13.

Razak, N S A., Marimuthu, M., Omar, A \& Mamat, M. (2014). Procedia: Social and Behavioral Sciences 130, 577-582.

Ray, S., Ow, T., \& Kim, S. S. (2011). Security assurance: How online service providers can influence security control perceptions and gain trust. Decision Sciences, 42(2), 391-412.

Rittichainuwat, B. N., Qu, H., \& Mongkhonvanit, C. (2006). A study of the impact of travel inhibitors on the likelihood of travelers' revisiting Thailand. Journal of Travel \& Tourism Marketing, 21(1), 77. 
Rousseau, D., Sitkin, S., Burt, R., \& Camerer, C. (1998). Not so different after all: A cross-discipline view of trust. Academy of Management Review, 23, 393-404.

Sila, I. (2015) .The state of empirical research on the adoption and diffusion of business-to-business e-commerce. International Journal of Electronic Business. 12(3) 258-301.

Su, L., Lian, Q., \& Huang, Y. (2020). How do tourists' attribution of destination social responsibility motives impact trust and intention to visit? The moderating role of destination reputation. Tourism Management, 77, 103970.

Tourism Authority of Thailand. (2010). TAT raises its digital profile with the launch of the 'Amazing Thailand' mobile application. Available at: http://www.tatnews.org (accessed on 13 June 2017).

Um, S., \& Crompton, J.L. (1990). Attitude determinants in tourism destination choice. Annals of Tourism Research, 17, 432-448.

Vail, M. W., Earp, J. B., \& Antón, A. I. (2008). An empirical study of consumer perceptions and comprehension of web site privacy policies. IEEE Transactions on Engineering Management, 55(3), 442-454.

Wang, Y., Qu, Z., \& Tan, B. (2018). How do assurance mechanisms interact in online marketplaces? A signaling perspective. IEEE Transactions on Engineering Management, 65(2), 239-251.

Wu, J.J., \& Chang, S.Y. (2005). Towards understanding members' interactivity, trust, and flow in online travel community. Industrial Management \& Data, 105(7), 937-954. 